\title{
An assessment of the impact of host polymorphisms on Plasmodium falciparum var gene expression patterns among Kenyan children
}

George M Warimwe ${ }^{1,2^{*}}$, Gregory Fegan ${ }^{1,3}$, Esther W Kiragu ${ }^{1}$, Jennifer N Musyoki ${ }^{1}$, Alexander W Macharia ${ }^{1}$, Kevin Marsh ${ }^{1,3}$, Thomas N Williams ${ }^{1,4}$ and Peter C Bull ${ }^{1,3}$

\begin{abstract}
Background: Host genotype accounts for a component of the variability in susceptibility to childhood Plasmodium falciparum malaria. However, despite numerous examples of host polymorphisms associated with tolerance or resistance to infection, direct evidence for an impact of host genetic polymorphisms on the in vivo parasite population is difficult to obtain. Parasite molecules whose expression is most likely to be associated with such adaptation are those that are directly involved in the host-parasite interaction. A prime candidate is the family of parasite var gene-encoded molecules on P. falciparum-infected erythrocytes, PfEMP1, which binds various host molecules and facilitates parasite sequestration in host tissues to avoid clearance by the spleen.
\end{abstract}

Methods: To assess the impact of host genotype on the infecting parasite population we used a published parasite var gene sequence dataset to compare var gene expression patterns between parasites from children with polymorphisms in molecules thought to interact with or modulate display of PfEMP1 on the infected erythrocyte surface: ABO blood group, haemoglobin S, alpha-thalassaemia, the T188G polymorphism of CD36 and the K29M polymorphism of ICAM1.

Results: Expression levels of 'group A-like' var genes, which encode a specific group of PfEMP1 variants previously associated with low host immunity and severe malaria, showed signs of elevation among children of blood group AB. No other host factor tested showed evidence for an association with var expression.

Conclusions: Our preliminary findings suggest that host $A B O$ blood group may have a measurable impact on the infecting parasite population. This needs to be verified in larger studies.

Keywords: Malaria, Host polymorphisn, Parasite var gene

\section{Background}

Host genetic factors have been estimated to account for up to $30 \%$ of the variability in the risk of developing malaria [1]. Whereas numerous studies have examined the effect of specific genetic polymorphisms on disease susceptibility and severity, relatively little attention has been paid to their direct impact on parasite gene expression patterns within the host. Such an effect may be most pronounced on parasite molecules that play a direct role

\footnotetext{
* Correspondence: george.warimwe@ndm.ox.ac.uk

'Kenya Medical Research Institute-Wellcome Trust Research Programme, Kilifi, Kenya

${ }^{2}$ The Jenner Institute, University of Oxford, Oxford, UK

Full list of author information is available at the end of the article
}

in the host-parasite interaction. The large family of cytoadhesive parasite molecules called PfEMP1 (P. falciparum erythrocyte membrane protein 1 ) fit this profile. These multi-domain proteins are encoded by $\sim 60$ clonally variant var genes that are present within the subtelomeric regions of most chromosomes and within some internal clusters. PfEMP1 are inserted into the infected erythrocyte (IE) surface where they bind to various host ligands resulting in IE sequestration in different body tissues [2]. Sequestration of IE in tissues is thought to prevent their passage through the spleen, where they may be effectively removed from circulation. During the blood stage of infection by $P$. falciparum, individual parasites switch between different var genes through an epigenetic mechanism 
that operates at least in part at the transcriptional level. Through this process they can alter both the cytoadhesive and antigenic properties of infected erythrocytes and thus prolong infection $[3,4]$. We would predict that expression of PfEMP1 by the infecting parasite population is very sensitive to both alterations in the composition of host receptors and in the composition of the erythrocyte surface itself. We and others have previously shown that host immunity imposes a selection pressure on the infecting parasite population such that a specific group of PfEMP1 variants are preferentially expressed in young children and those with a poorly developed repertoire of IE surface antibodies [5-7]. However, whether host genotype influences PfEMP1 expression patterns in an infecting parasite population remains unknown. This could occur, first, through host polymorphisms that alter the concentration of specific PfEMP1 ligands in the body. Within this scenario, polymorphisms in one host molecule may select against expression of PfEMP1 variants requiring that molecule for cytoadhesion. Parasites expressing such variants would therefore be left vulnerable to clearance by the spleen while those expressing PfEMP1 variants that can utilize other host molecules for cytoadhesion will evade splenic clearance and dominate the infection. Second, modification of PfEMP1 expression could occur if genetic variants accelerate the rate at which antibodies to the surface of IEs are acquired (this has been described for genetic variants of haemoglobin; [8-10]). Given that host IE surface antibodies are associated with parasite var gene expression patterns in vivo [7], differences in the hostPfEMP1 interaction with respect to such genotypes may be expected.

Here, to investigate the influence of host genotype on the infecting parasite population we compared var gene expression patterns among clinical isolates from Kenyan children in relation to: 1) three host polymorphisms in molecules to which PfEMP1 binds (namely, the T188G polymorphism of CD36 [11], the K29M polymorphism of ICAM1 [12] and ABO blood group [13]) and, 2) two host genetic variants of haemoglobin that accelerate the rate at which antibodies to the surface of IEs are acquired, alpha-thalassaemia and $\mathrm{HbS}$ [8-10].

\section{Methods}

\section{Study site and participants}

We used a published dataset of children presenting to hospital with clinical malaria $(\mathrm{N}=217)$ and asymptomatic infections $(\mathrm{N}=33)$ for all the analysis presented here $[7,14]$. This dataset was specifically designed to evaluate the relationship between parasite var gene expression patterns and immunity to clinical malaria as described $[7,14]$. However various host genotype data were also available for most children thus allowing an exploratory analysis on the effect of host genotype on parasite var gene expression patterns. The study was carried out at Kilifi District Hospital, situated at the coast of Kenya, following ethical approval by the Kenya Medical Research Institute Ethical Review Committee. Informed consent was obtained from parents/guardians of all study participants.

Clinical malaria was defined as fever plus $\geq 1$ or more trophozoites per 100 uninfected erythrocytes $[7,14]$. Severe malaria was defined as a hospital admission with any of the three major clinical syndromes that tend to be observed in African children [15,16] namely: severe malarial anemia (haemoglobin concentration of $<5 \mathrm{~g} / \mathrm{dL}$ ), impaired consciousness (Blantyre coma score $<4$ in patients under 8 months old or $<5$ in patients aged $\geq 8$ months) and respiratory distress (deep 'Kussmaul' breathing pattern). The clinical malaria patients were sampled between August 2003 and September 2007 while children with asymptomatic infection of any parasite density were sampled in May 2007 during a population based crosssectional survey.

\section{Host genotyping}

Published methods were used for host genotyping of the T188G polymorphism of CD36 and K29M polymorphism of ICAM1 [17], alpha-thalassaemia [18] and HbAS [19]. $\mathrm{ABO}$ blood group for each patient was determined using standard slide haemagglutination.

\section{Parasite sampling and var sequence classification}

Expressed var sequence tags were generated from cDNA obtained from ring-stage parasite isolates obtained from all 250 children before culture using published methods [6]. PCR amplified var tags were ligated into plasmids and sub-cloned into bacteria. For each parasite isolate, up to 96 individual bacterial colonies were picked, and plasmid DNA prepared for capillary sequencing. Sequence assembly, classification and counting were then done using two published analysis pipelines $[7,20]$. For each parasite isolate the number of bacterial colonies carrying cys2 var sequences and each of three previously described cys2 sequence subgroups i.e. MFK + REY-, MFK-REY + and MFK-REY- [6] was expressed as a percentage of the total number of colonies sequenced and this proportion was used for the analysis. Using another published classification approach we also classified cys 2 sequences as "group A-like" if they contained any of a set of 573 polymorphic sequence blocks $[7,21]$. For each parasite isolate the number of colonies carrying group A-like sequences was also expressed as a percentage of the number of colonies sequenced.

\section{Statistical analysis}

Analysis was performed using Stata $^{\text {tw }}$ statistical software version 11. Before use in linear regression models the percentage sequence expression levels were arcsine- 
transformed as described previously $[7,14]$. Linear regression analysis was performed with binary variables for each blood group phenotype, that is, blood groups $\mathrm{A}, \mathrm{B}, \mathrm{AB}$ and $\mathrm{O}$, with the latter used as the reference for comparison. For all other host molecules, the respective allelic states (i.e. heterozygous and homozygous) were used simultaneously as explanatory variables so that the results are relative to the wild type genotype (Table 1 ). We tested for an association between each polymorphism and expression levels of five markers of the parasite var gene expression profile that tend to be differentially associated with host immunity: i) the overall proportion of expressed var gene sequences that are classified as cys 2 and, ii) the proportion of cys 2 var genes that fall in the MFK + REY-, iii) MFK-REY+, iv) MFK-REY- or v) group A-like subgroup. Our aim was to determine whether host polymorphism have an independent effect on var gene expression and hence all regression models were adjusted for covariates previously found to be associated with cys2 var gene expression levels in the primary publications on this dataset namely: host age, IE surface antibody levels (measured as the median IgG response to the IE surface of 8 clinical isolates by flow cytometry) and infection type at sampling (coded as binary variables for either mild malaria, malaria with impaired consciousness, malaria with respiratory distress, severe malarial anemia or asymptomatic infection) $[7,14]$. The validity of the observed relationships was confirmed by checking the normality of the residuals from the regression models. The interquartile ranges of the residuals had no severe outliers thus providing no evidence to reject normality of the residuals at a $5 \%$ alpha level.

\section{Results and discussion}

We used published var gene sequence data from 250 isolates obtained from children with clinical malaria $(\mathrm{N}=217$, of who 111 had severe malaria) or with asymptomatic infection $(\mathrm{N}=33)$ for this analysis ([EMBL accession numbers FN588437-FN592661, HE654181-HE654544]) [7,14]. The median age of the 217 children with clinical malaria was 3 years (interquartile range (IQR) 1.8 to 4.2 ) while those with asymptomatic infection had a median age of 5.4 years (IQR 4.1 to 6.7). Neither age nor IE surface antibodies differed between the host polymorphisms considered here (Kruskal-Wallis test $p>0.05$ for all), with the exception of HbAS, which showed a positive association with IE surface antibodies (Mann-Whitney U test $p=$ 0.02 ) as observed in previous studies $[9,10,22]$. For each host polymorphism Table 1 summarizes the number of children with data available and their distribution. Table 2 provides a comparison of frequencies of each host polymorphism in our dataset with those observed in previous studies in the same geographical setting.

Whilst the proportion of sampled var sequences broadly classified as cys2 showed no association with any host polymorphism, there was evidence for an association between elevated expression of the group A-like cys2 var subgroup and blood group $\mathrm{AB}$ (Beta $=0.25,95 \% \mathrm{CI}$ $0.07,0.44, p=0.008$ ) but not with blood groups $\mathrm{A}$ $($ Beta $=-0.004,95 \% \mathrm{CI}-0.10,0.09, p=0.9)$ or B (Beta $=$ $0.08,95 \%$ CI $-0.02,0.19, p=0.1$ ) (Table 1). However, given the number of comparisons that were performed overall this should be considered preliminary.

Children of blood group $\mathrm{A}, \mathrm{B}$ or $\mathrm{AB}$ tend to be more susceptible to severe malaria than those of blood group $\mathrm{O}[23,26]$. The association between carriage of the blood group $\mathrm{AB}$ and high group A-like var gene expression is thus consistent with the fact that parasite isolates from children with severe malaria tend to express higher levels of group A-like var genes [7,27-29]. In our dataset, parasite rosetting, defined as the spontaneous binding of infected to uninfected erythrocytes, was strongly correlated with group A-like var expression $(\mathrm{N}=133$, rho = $0.46, p<0.0001 ;[14])$. However, despite the observed association between blood group $\mathrm{AB}$ and high group $\mathrm{A}-$ like var expression (Table 1), among isolates with rosetting data available $(\mathrm{N}=133)$ parasite rosetting frequency only correlated with blood groups A (Beta $=0.12$, 95\% CI 0.005, 0.24, $p=0.04$ ) and B (Beta $=0.18,95 \%$ CI 0.04, $0.31, p=0.01$ ), but not $\mathrm{AB}$ (Beta $=0.04,95 \%$ CI -0.18 , $0.25, p=0.7)$ in a regression analysis adjusted for host age, IE surface antibodies and infection type (also see Figure 1). Though this may seem counterintuitive, the lack of correlation between blood group $\mathrm{AB}$ and rosetting is not incompatible with this observation because only a subset of group A var genes are known to promote rosetting [30] so it is quite possible that selection for group A PfEMP1 can occur without an increase in the rosetting phenotype. It is therefore possible that, together with age, IE surface antibodies and rosetting, the blood group $\mathrm{AB}$ phenotype contributes to the in vivo selection pressures that promote group A-like var gene expression in the infecting parasite population. To explore this further, we analyzed the relationship again using the same regression analysis framework but instead considering the blood group antigens A and B as individual alleles. In this analysis group A-like var gene expression shows evidence of an association with carriage of the blood group B antigen (Beta $=0.12,95 \%$ CI 0.03, 0.21, $p=0.008)$, but the blood group $\mathrm{A}$ antigen does not (Beta $=0.03,95 \%$ CI $-0.06,0.11, p=0.5$ ). The sample size was too small to test for an interaction between these two antigens. It is currently unclear what would drive this selection and this observation clearly needs to be verified in further studies.

As shown in Table 1, none of the other host polymorphisms considered here showed an association with detectable alterations in patterns of parasite var gene expression, though parasites from HbAS children had 
Table 1 Relationship between host genotype and parasite var gene expression

\begin{tabular}{|c|c|c|c|c|c|c|}
\hline Host polymorphism & Type, no. in dataset & $\begin{array}{c}\text { Cys2 var group } \\
\text { Beta }(95 \% \mathrm{Cl}), p \text { value }\end{array}$ & $\begin{array}{l}\text { Group A-like subgroup } \\
\text { Beta }(95 \% \mathrm{Cl}), p \text { value }\end{array}$ & $\begin{array}{l}\text { MFK + REY- subgroup } \\
\text { Beta }(95 \% \mathrm{Cl}), p \text { value }\end{array}$ & $\begin{array}{l}\text { MFK-REY + subgroup } \\
\text { Beta }(95 \% \mathrm{Cl}), p \text { value }\end{array}$ & $\begin{array}{l}\text { MFK-REY- subgroup } \\
\text { Beta }(95 \% \mathrm{Cl}), p \text { value }\end{array}$ \\
\hline \multirow{4}{*}{ ABO blood group } & Blood group O, 108 & 0 & 0 & 0 & 0 & 0 \\
\hline & Blood group A, 76 & $0.004(-0.10,0.11), p=0.9$ & $-0.004(-0.10,0.09), p=0.9$ & $-0.004(-0.09,0.08), p=0.9$ & $0.01(-0.07,0.09), p=0.8$ & $-0.01(-0.09,0.06), p=0.7$ \\
\hline & Blood group B, 54 & $0.05(-0.07,0.16), p=0.4$ & $0.08(-0.02,0.19), p=0.1$ & $0.08(-0.02,0.17), p=0.1$ & $0.01(-0.08,0.09), p=0.8$ & $-0.01(-0.09,0.07), p=0.8$ \\
\hline & Blood group $A B, 12$ & $0.13(-0.08,0.34), p=0.2$ & $0.25(0.07,0.44), p=0.008$ & $0.07(-0.10,0.24), p=0.4$ & $0.06(-0.10,0.21), p=0.5$ & $0.02(-0.12,0.17), p=0.8$ \\
\hline \multirow{3}{*}{ CD36 (T188G) } & Wild type (T/T), 153 & 0 & 0 & 0 & 0 & 0 \\
\hline & Heterozygous (T/G), 22 & $0.08(-0.06,0.23), p=0.3$ & $0.03(-0.10,0.15), p=0.7$ & $0.03(-0.08,0.14), p=0.6$ & $-0.01(-0.12,0.11), p=0.9$ & $0.07(-0.04,0.18), p=0.2$ \\
\hline & Homozygous (G/G), 1 & ND & ND & ND & ND & ND \\
\hline \multirow{3}{*}{ ICAM1 (K29M) } & Wild type (K29/K29), 79 & 0 & 0 & 0 & 0 & 0 \\
\hline & Heterozygous (K29/M29), 74 & $-0.03(-0.13,0.07), p=0.6$ & $-0.07(-0.16,0.02), p=0.1$ & $-0.03(-0.11,0.05), p=0.4$ & $0.04(-0.04,0.12), p=0.3$ & $-0.06(-0.14,0.01), p=0.1$ \\
\hline & Homozygous (M29/M29), 23 & $-0.05(-0.21,0.10), p=0.5$ & $-0.01(-0.15,0.12), p=0.9$ & $0.06(-0.06,0.17), p=0.3$ & $-0.07(-0.20,0.05), p=0.2$ & $-0.09(-0.20,0.03), p=0.1$ \\
\hline \multirow{3}{*}{$\mathrm{HbS}$} & Wild type (HbAA), 198 & 0 & 0 & 0 & 0 & 0 \\
\hline & Heterozygous (HbAS), 12 & $-0.19(-0.40,0.01), p=0.07$ & $-0.18(-0.37,0.01), p=0.07$ & $-0.08(-0.25,0.09), p=0.4$ & $-0.08(-0.25,0.08), p=0.3$ & $-0.10(-0.25,0.05), p=0.2$ \\
\hline & Homozygous (HbSS), 1 & ND & ND & ND & ND & ND \\
\hline \multirow{3}{*}{ Alpha-thalassaemia } & Wild type (aa/aa), 77 & 0 & 0 & 0 & 0 & 0 \\
\hline & Heterozygous (-a/aa), 106 & $0.10(-0.001,0.20), p=0.05$ & $0.06(-0.03,0.16), p=0.2$ & $0.07(-0.01,0.15), p=0.08$ & $-0.01(-0.09,0.07), p=0.8$ & $0.04(-0.03,0.11), p=0.3$ \\
\hline & Homozygous $(-a /-a), 31$ & $0.03(-0.11,0.18), p=0.6$ & $0.02(-0.11,0.16), p=0.7$ & $0.03(-0.09,0.14), p=0.6$ & $-0.05(-0.17,0.06), p=0.3$ & $0.06(-0.04,0.17), p=0.2$ \\
\hline
\end{tabular}


Table 2 Summary of host polymorphism frequencies in the study

\begin{tabular}{|c|c|c|c|}
\hline $\begin{array}{l}\text { Host } \\
\text { polymorphism }\end{array}$ & Allelic states & $\begin{array}{c}\text { Frequency } \\
\text { in dataset } \\
(\%)\end{array}$ & $\begin{array}{c}\text { Frequency in } \\
\text { previous studies } \\
\text { (Reference) }\end{array}$ \\
\hline \multirow{5}{*}{$\begin{array}{l}\text { ABO blood } \\
\text { group }\end{array}$} & Blood group $\mathrm{O}$ & $108(43.2 \%)$ & $44.7 \%[23]$ \\
\hline & Blood group A & $76(30.4 \%)$ & $25.5 \%[23]$ \\
\hline & Blood group B & $54(21.6 \%)$ & $20.2 \%[23]$ \\
\hline & Blood group $A B$ & $12(4.8 \%)$ & $9.6 \%[23]$ \\
\hline & Wild type $(T / T)$ & $153(86.9 \%)$ & $83.5 \%[11]$ \\
\hline \multirow[t]{3}{*}{ CD36 (T188G) } & Heterozygous (T/G) & $22(12.5 \%)$ & $15.6 \%[11]$ \\
\hline & Homozygous (G/G) & $1(0.6 \%)$ & $0.9 \%[11]$ \\
\hline & Wild type (K29/K29) & 79 (44.9\%) & $45 \%[12]$ \\
\hline \multirow[t]{3}{*}{ ICAM1 (K29M) } & Heterozygous (K29/M29) & $74(42.0 \%)$ & $44 \%[12]$ \\
\hline & Homozygous (M29/M29) & $23(13.1 \%)$ & $11 \%[12]$ \\
\hline & Wild type (HbAA) & $198(93.8 \%)$ & $91.8 \%[24]$ \\
\hline \multirow[t]{2}{*}{$\mathrm{HbS}$} & Heterozygous (HbAS) & $12(5.7 \%)$ & $7.7 \%[24]$ \\
\hline & Homozygous (HbSS) & $1(0.5 \%)$ & $0.5 \%[24]$ \\
\hline \multirow{3}{*}{$\begin{array}{l}\text { Alpha- } \\
\text { thalassaemia }\end{array}$} & Wild type (aa/aa) & 77 (36.0\%) & $35 \%[25]$ \\
\hline & Heterozygous (-a/aa) & $106(49.5 \%)$ & $48 \%[25]$ \\
\hline & Homozygous $(-a /-a)$ & $31(14.5 \%)$ & $17 \%[25]$ \\
\hline
\end{tabular}

The proportion of children with each host polymorphism in the present study is compared to proportions observed in previous studies in the same geographical setting and the respective publications indicated.

somewhat lower expression levels of the group A-like var subgroup when compared to those from children with wild type hemoglobin (Table 1). The homozygous states of $\mathrm{HbS}$ and the CD36 T188G polymorphism were poorly represented in this dataset (one child each) and hence their effect on parasite var gene expression was not formally assessed.

Previous studies have noted the abnormal display of PfEMP1 on the surface of infected erythrocytes from
HbAS individuals that correlates with poor endothelial binding properties of such IE, perhaps providing a mechanical basis for the malaria-protective effect of $\mathrm{HbAS}$ [31,32]. In our analysis HbAS children had high IE surface antibody levels (see above) and notably low group A-like var expression levels though this latter observation did not reach the conventional level of statistical significance (Beta $=-0.18,95 \%$ CI $-0.37,0.01, p=0.07$; see Table 1). However, removal of IE surface antibodies as a covariate in the regression modeling strengthened this inverse relationship between $\mathrm{HbAS}$ and group Alike var expression (Beta $=-0.21,95 \%$ CI $-0.41,-0.02$, $p=0.03$ ). The possibility that low group A-like var expression levels in HbAS children results from the enhanced IE surface antibody response associated with this host genotype clearly needs further study. Future studies with better host genotype representation also need to consider the poorly understood host-parasite relationship among children with sickle cell disease (HbSS), a major risk factor for death from malaria [24], as well as the known negative epistasis in the malaria-protective effects of HbAS and alpha-thalassaemia [19].

Finally, we predicted an association between parasite var gene expression and polymorphisms in ICAM1 and CD36 based on the hypothesis that the reduced in vivo concentration of these host ligands resulting from the polymorphisms would give a growth advantage to parasites expression PfEMP1 that can bind to different host ligands. The lack of an association between these polymorphisms and group A-like var expression seems inconsistent with previous observations that group A PfEMP1 tend to bind poorly to ICAM1 and CD36 [33,34]. However our observation is consistent with previous studies in which the cytoadhesion phenotype of parasites sampled from children was compared in individuals with these polymorphisms $[35,36]$. Furthermore, a recent study shows
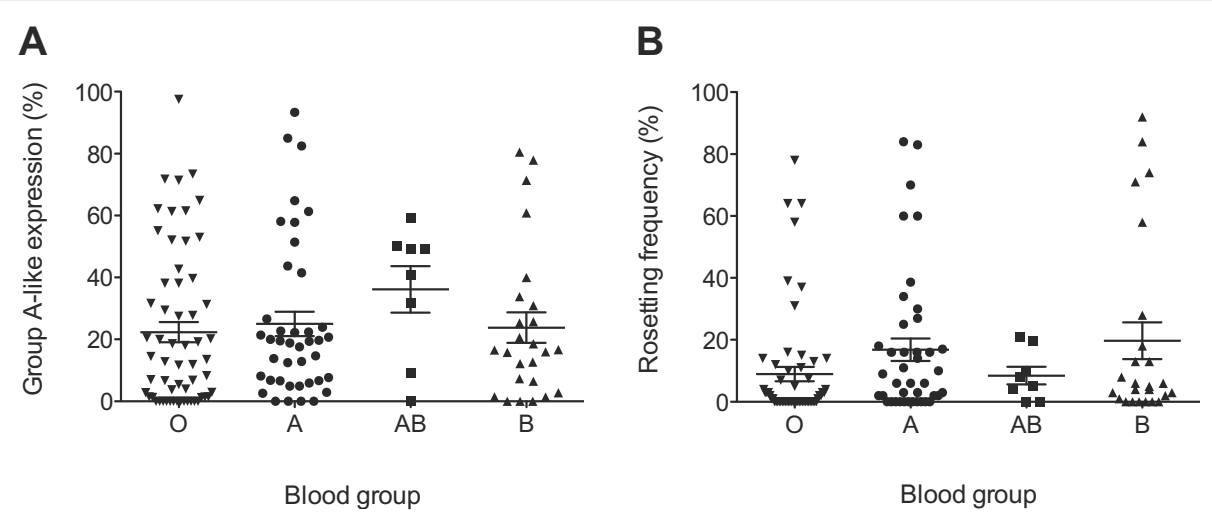

Figure 1 Parasite group A-like var expression and rosetting in children of different blood groups. The relationship between parasite group A-like var expression and blood group $(\mathbf{A})$ and the distribution of parasite rosetting frequencies in isolates from children of different $\mathrm{ABO}$ blood groups is shown. The data in both $(\mathbf{A})$ and $(\mathbf{B})$ represent isolates from each of 133 children whose parasite rosetting data were available, and the mean and standard errors of the mean are shown for each $\mathrm{ABO}$ blood group. 
that some group A PfEMP1 also bind to ICAM1 making this association less easy to predict [37]. We also note that the proportion of expressed group A-like var sequences in the isolate from the only CD36 T188G homozygote in our dataset (12.7\%) was below the lower 95\% confidence interval of the mean expression levels in isolates from heterozygote (mean $=26.1 \%, 95 \%$ CI $15.4 \%, 36.9 \%$ ) and wild type children $($ mean $=24.1 \%, 95 \%$ CI 20.4\%, 27.8\%). This may suggest that the effect of this host polymorphism on parasite var expression is only evident among homozygotes. Further studies with more T188G CD36 homozygotes are needed to test this.

\section{Conclusions}

In summary, despite sample size limitations for all host factors considered here, our preliminary evidence suggests that host genotype has a potential role in influencing var gene expression patterns in the infecting parasite population. More studies with the primary aim of evaluating the effect of host genotype on the whole parasite transcriptome could be a useful approach to validating and understanding mechanisms of host resistance and tolerance to P. falciparum infection.

\section{Abbreviations \\ PfEMP1: Plasmodium falciparum erythrocyte membrane protein 1; IE: Infected erythrocyte; ICAM1: Intercellular adhesion molecule 1.}

\section{Competing interests}

The authors declare that they have no competing interests.

\section{Authors' contributions}

$P C B, K M$, and TNW: designed research and provided overall project supervision. GMW, EWK, JNM, AWM, and PCB: processed samples, performed var sequence classification and host genotyping. GMW, GF, and PCB: performed statistical analysis. GMW wrote manuscript with critical input from all authors. All authors read and approved the final manuscript.

\section{Acknowledgements}

We are grateful to Matt Berriman, Arnab Pain and the Wellcome Trust Sanger Institute sequencing operations staff for producing the sequence data, and Thomas Keane for sequence assembly. This paper is published with the permission of the Director of KEMRI. PCB and GMW were supported by Wellcome Trust Programme Grants (084535 and 077092 to PCB and KM) and Project Grant (076030 to PCB and KM). GMW was also supported by a Wellcome Trust Strategic Award (084538 to KM). TNW was supported by a Wellcome Trust Programme Grant (076934) and the European Union EVIMalR network of excellence.

\footnotetext{
Author details

'Kenya Medical Research Institute-Wellcome Trust Research Programme, Kilifi, Kenya. ${ }^{2}$ The Jenner Institute, University of Oxford, Oxford, UK. ${ }^{3}$ Nuffield Department of Clinical Medicine, University of Oxford, Oxford, UK.

${ }^{4}$ Department of Medicine, Imperial College, London, UK.

Received: 17 February 2014 Accepted: 24 September 2014

Published: 29 September 2014

\section{References}

1. Mackinnon MJ, Mwangi TW, Snow RW, Marsh K, Williams TN: Heritability of Malaria in Africa. PLoS Med 2005, 2(12):e340.

2. Gardner MJ, Hall N, Fung E, White O, Berriman M, Hyman RW, Carlton JM, Pain A, Nelson KE, Bowman S, Paulsen IT, James K, Eisen JA, Rutherford K, Salzberg SL, Craig A, Kyes S, Chan MS, Nene V, Shallom SJ, Suh B,
}

Peterson J, Angiuoli S, Pertea M, Allen J, Selengut J, Haft D, Mather MW, Vaidya AB, Martin DM, et al: Genome sequence of the human malaria parasite Plasmodium falciparum. Nature 2002, 419(6906):498-511.

3. Guizetti J, Scherf A: Silence, activate, poise and switch! Mechanisms of antigenic variation in Plasmodium falciparum. Cell Microbiol 2013, 15(5):718-726.

4. Jiang $L$, Mu J, Zhang Q, Ni T, Srinivasan P, Rayavara K, Yang W, Turner $L$, Lavstsen T, Theander TG, Peng W, Wei G, Jing Q, Wakabayashi Y, Bansal A, Luo Y, Ribeiro JM, Scherf A, Aravind L, Zhu J, Zhao K, Miller LH: PfSETvs methylation of histone H3K36 represses virulence genes in Plasmodium falciparum. Nature 2013, 499(7457):223-227.

5. Cham GK, Turner L, Lusingu J, Vestergaard L, Mmbando BP, Kurtis JD, Jensen AT, Salanti A, Lavstsen T, Theander TG: Sequential, ordered acquisition of antibodies to Plasmodium falciparum erythrocyte membrane protein 1 domains. J Immunol 2009, 183(5):3356-3363.

6. Bull PC, Berriman M, Kyes S, Quail MA, Hall N, Kortok MM, Marsh K, Newbold Cl: Plasmodium falciparum variant surface antigen expression patterns during malaria. PLoS Pathog 2005, 1(3):e26.

7. Warimwe GM, Keane TM, Fegan G, Musyoki JN, Newton CR, Pain A, Berriman M, Marsh K, Bull PC: Plasmodium falciparum var gene expression is modified by host immunity. Proc Natl Acad Sci U S A 2009, 106(51):21801-21806.

8. Williams TN, Weatherall DJ, Newbold CI: The membrane characteristics of Plasmodium falciparum-infected and -uninfected heterozygous alpha(0) thalassaemic erythrocytes. Br J Haematol 2002, 118(2):663-670.

9. Verra F, Simpore J, Warimwe GM, Tetteh KK, Howard T, Osier FH, Bancone G, Avellino P, Blot I, Fegan G, Bull PC, Williams TN, Conway DJ, Marsh K, Modiano D: Haemoglobin $C$ and $S$ role in acquired immunity against Plasmodium falciparum malaria. PLOS ONE 2007, 2(10):e978.

10. Cabrera G, Cot M, Migot-Nabias F, Kremsner PG, Deloron P, Luty AJ: The sickle cell trait is associated with enhanced immunoglobulin $G$ antibody responses to Plasmodium falciparum variant surface antigens. $J$ Infect Dis 2005, 191(10):1631-1638.

11. Pain A, Urban BC, Kai O, Casals-Pascual C, Shafi J, Marsh K, Roberts DJ: A non-sense mutation in $\mathrm{Cd} 36$ gene is associated with protection from severe malaria. Lancet 2001, 357(9267):1502-1503.

12. Fernandez-Reyes D, Craig AG, Kyes SA, Peshu N, Snow RW, Berendt AR, Marsh $\mathrm{K}$, Newbold Cl: A high frequency African coding polymorphism in the N-terminal domain of ICAM-1 predisposing to cerebral malaria in Kenya. Hum Mol Genet 1997, 6(8):1357-1360.

13. Chen Q, Heddini A, Barragan A, Fernandez V, Pearce SF, Wahlgren M: The semiconserved head structure of Plasmodium falciparum erythrocyte membrane protein 1 mediates binding to multiple independent host receptors. J Exp Med 2000, 192(1):1-10.

14. Warimwe GM, Fegan G, Musyoki JN, Newton CR, Opiyo M, Githinji G, Andisi C, Menza F, Kitsao B, Marsh K, Bull PC: Prognostic indicators of life-threatening malaria are associated with distinct parasite variant antigen profiles. Science Translational Med 2012, 4(129):129-145.

15. Marsh K, Forster D, Waruiru C, Mwangi I, Winstanley M, Marsh V, Newton C, Winstanley P, Warn P, Peshu N: Indicators of life-threatening malaria in African children. N Engl J Med 1995, 332(21):1399-1404.

16. Newton CR, Valim C, Krishna S, Wypij D, Olola C, Agbenyega T, Taylor TE: The prognostic value of measures of acid/base balance in pediatric falciparum malaria, compared with other clinical and laboratory parameters. Clin Infect Dis 2005, 41(7):948-957.

17. Bull PC, Pain A, Ndungu FM, Kinyanjui SM, Roberts DJ, Newbold Cl, Marsh K: Plasmodium falciparum antigenic variation: relationships between in vivo selection, acquired antibody response, and disease severity. J Infect Dis 2005, 192(6):1119-1126.

18. Chong SS, Boehm CD, Higgs DR, Cutting GR: Single-tube multiplex-PCR screen for common deletional determinants of alpha-thalassemia. Blood 2000, 95(1):360-362.

19. Williams TN, Mwangi TW, Wambua S, Peto TE, Weatherall DJ, Gupta S, Recker M, Penman BS, Uyoga S, Macharia A, Mwacharo JK, Snow RW, Marsh K: Negative epistasis between the malaria-protective effects of alpha +-thalassemia and the sickle cell trait. Nat Genet 2005, 37(11):1253-1257.

20. Bull PC, Kyes S, Buckee CO, Montgomery J, Kortok MM, Newbold Cl, Marsh K: An approach to classifying sequence tags sampled from Plasmodium falciparum var genes. Mol Biochem Parasitol 2007, 154(1):98-102. 
21. Bull PC, Buckee CO, Kyes S, Kortok MM, Thathy V, Guyah B, Stoute JA, Newbold Cl, Marsh K: Plasmodium falciparum antigenic variation. Mapping mosaic var gene sequences onto a network of shared, highly polymorphic sequence blocks. Mol Microbiol 2008, 68(6):1519-1534.

22. Marsh K, Otoo L, Hayes RJ, Carson DC, Greenwood BM: Antibodies to blood stage antigens of Plasmodium falciparum in rural Gambians and their relation to protection against infection. Trans $R$ Soc Trop Med Hyg 1989, 83(3):293-303.

23. Rowe JA, Handel IG, Thera MA, Deans AM, Lyke KE, Kone A, Diallo DA, Raza A, Kai O, Marsh K, Plowe CV, Doumbo OK, Moulds JM: Blood group O protects against severe Plasmodium falciparum malaria through the mechanism of reduced rosetting. Proc Natl Acad Sci U S A 2007, 104(44):17471-17476.

24. McAuley CF, Webb C, Makani J, Macharia A, Uyoga S, Opi DH, Ndila C, Ngatia A, Scott JA, Marsh K, Williams TN: High mortality from Plasmodium falciparum malaria in children living with sickle cell anemia on the coast of Kenya. Blood 2010, 116(10):1663-1668.

25. Wambua S, Mwangi TW, Kortok M, Uyoga SM, Macharia AW, Mwacharo JK, Weatherall DJ, Snow RW, Marsh K, Williams TN: The Effect of alpha(+)-Thalassaemia on the Incidence of Malaria and Other Diseases in Children Living on the Coast of Kenya. PLoS Med 2006, 3(5):e158.

26. Fry AE, Griffiths MJ, Auburn S, Diakite M, Forton JT, Green A, Richardson A, Wilson J, Jallow M, Sisay-Joof F, Pinder M, Peshu N, Williams TN, Marsh K, Molyneux ME, Taylor TE, Rockett KA, Kwiatkowski DP: Common variation in the $A B O$ glycosyltransferase is associated with susceptibility to severe Plasmodium falciparum malaria. Hum Mol Genet 2008, 17(4):567-576.

27. Kyriacou HM, Stone GN, Challis RJ, Raza A, Lyke KE, Thera MA, Kone AK, Doumbo OK, Plowe CV, Rowe JA: Differential var gene transcription in Plasmodium falciparum isolates from patients with cerebral malaria compared to hyperparasitaemia. Mol Biochem Parasitol 2006, 150(2):211-218

28. Normark J, Nilsson D, Ribacke U, Winter G, Moll K, Wheelock CE, Bayarugaba J, Kironde F, Egwang TG, Chen Q, Andersson B, Wahlgren M: PfEMP1-DBL1alpha amino acid motifs in severe disease states of Plasmodium falciparum malaria. Proc Natl Acad Sci U S A 2007, 104(40):15835-15840

29. Kirchgatter K, Portillo Hdel A: Association of severe noncerebral Plasmodium falciparum malaria in Brazil with expressed PfEMP1 DBL1 alpha sequences lacking cysteine residues. Mol Med 2002, 8(1):16-23.

30. Ghumra A, Semblat JP, Ataide R, Kifude C, Adams Y, Claessens A, Anong DN, Bull PC, Fennell C, Arman M, Amambua-Ngwa A, Walther M, Conway DJ, Kassambara L, Doumbo OK, Raza A, Rowe JA: Induction of straintranscending antibodies against Group A PfEMP1 surface antigens from virulent malaria parasites. PLoS Pathog 2012, 8(4):e1002665.

31. Cholera R, Brittain NJ, Gillrie MR, Lopera-Mesa TM, Diakite SA, Arie T, Krause MA, Guindo A, Tubman A, Fujioka H, Diallo DA, Doumbo OK, Ho M, Wellems TE, Fairhurst RM: Impaired cytoadherence of Plasmodium falciparum-infected erythrocytes containing sickle hemoglobin. Proc Natl Acad Sci U S A 2008, 105(3):991-996.

32. Fairhurst RM, Bess CD, Krause MA: Abnormal PfEMP1/knob display on Plasmodium falciparum-infected erythrocytes containing hemoglobin variants: fresh insights into malaria pathogenesis and protection. Microbes Infect 2012, 14(10):851-862.

33. Janes JH, Wang CP, Levin-Edens E, Vigan-Womas I, Guillotte M, Melcher M, Mercereau-Puijalon O, Smith JD: Investigating the host binding signature on the Plasmodium falciparum PfEMP1 protein family. PLOS Pathog 2011 7(5):e1002032

34. Robinson BA, Welch TL, Smith JD: Widespread functional specialization of Plasmodium falciparum erythrocyte membrane protein 1 family members to bind CD36 analysed across a parasite genome. Mol Microbiol 2003, 47(5):1265-1278.

35. Beaudry JT, Krause MA, Diakite SA, Fay MP, Joshi G, Diakite M, White NJ, Fairhurst RM: Ex-vivo cytoadherence phenotypes of Plasmodium falciparum strains from Malian children with hemoglobins $A, S$, and $C$. PLOS ONE 2014, 9(3):e92185.

36. Ochola LB, Siddondo BR, Ocholla H, Nkya S, Kimani EN, Williams TN, Makale JO, Liljander A, Urban BC, Bull PC, Szestak T, Marsh K, Craig AG:
Specific Receptor Usage in Plasmodium falciparum Cytoadherence Is Associated with Disease Outcome. PLOS ONE 2011, 6(3):e14741.

37. Bengtsson A, Joergensen L, Rask TS, Olsen RW, Andersen MA, Turner L, Theander TG, Hviid L, Higgins MK, Craig A, Brown A, Jensen AT: A novel domain cassette identifies Plasmodium falciparum PfEMP1 proteins binding ICAM-1 and is a target of cross-reactive, adhesion-inhibitory antibodies. J Immunol 2013, 190(1):240-249.

doi:10.1186/1471-2334-14-524

Cite this article as: Warimwe et al: An assessment of the impact of host polymorphisms on Plasmodium falciparum var gene expression patterns among Kenyan children. BMC Infectious Diseases 2014 14:524.

\section{Submit your next manuscript to BioMed Central and take full advantage of:}

- Convenient online submission

- Thorough peer review

- No space constraints or color figure charges

- Immediate publication on acceptance

- Inclusion in PubMed, CAS, Scopus and Google Scholar

- Research which is freely available for redistribution

Submit your manuscript at www.biomedcentral.com/submit
C BioMed Central 